\title{
Arsenic sulfide, the main component of realgar, a traditional Chinese medicine, induces apoptosis of gastric cancer cells in vitro and in vivo
}

This article was published in the following Dove Press journal:

Drug Design, Development and Therapy

16 December 2014

Number of times this article has been viewed

\author{
Lian Zhangl,* \\ Wei Tian ${ }^{1,2, *}$ \\ Sungkyoung Kim' \\ Wenping Ding' \\ Yingying Tong' \\ Siyu Chen'
}

'Department of Oncology, Xin Hua Hospital Affiliated to Shanghai Jiao

Tong University School of Medicine, Shanghai, People's Republic of China ${ }^{2}$ Department of Oncology, Central Hospital of Zibo, Shandong, People's Republic of China

*These authors contributed equally to this work
Correspondence: Siyu Chen Department of Oncology, Xin Hua Hospital Affiliated to Shanghai Jiao Tong University School of Medicine, No 1665, Kong Jiang Road, Shanghai 200092, People's Republic of China Tel +86 2I 25077642 Email siyu.chen@shsmu.edu.cn
Background: Arsenic sulfide $\left(\mathrm{As}_{4} \mathrm{~S}_{4}\right)$, the main component of realgar, a traditional Chinese medicine, has shown antitumor efficacy in several tumor types, especially for acute promyelocytic leukemia. In this study, we aimed to explore the efficacy and mechanism of $\mathrm{As}_{4} \mathrm{~S}_{4}$ in gastric cancer. Methods: The effect of $\mathrm{As}_{4} \mathrm{~S}_{4}$ on cell proliferation and apoptosis of gastric cancer cells was investigated by MTT assay, 4',6-diamidino-2-phenylindole (DAPI) staining, and annexin $\mathrm{V}$-fluorescein isothiocyanate/propidium iodide staining using gastric cancer cell lines AGS (harboring wild-type p53) and MGC803 (harboring mutant p53) in vitro. The expression of apoptosis-related proteins was measured by Western blotting, real-time polymerase chain reaction, and immunohistochemistry analysis. Mouse xenograft models were established by inoculation with MGC803 cells, and the morphology and the proportion of apoptotic cells in tumor tissues were detected by hematoxylin and eosin staining and TdT-mediated dUTP nick end labeling (TUNEL) assay, respectively.

Results: $\mathrm{As}_{4} \mathrm{~S}_{4}$ inhibited the proliferation and induced apoptosis of AGS and MGC803 cells in a time- and dose-dependent manner. $\mathrm{As}_{4} \mathrm{~S}_{4}$ upregulated the expression of Bax and MDM2 while downregulated the expression of Bcl-2. The expression of p53 increased significantly in the AGS cells but did not readily increase in the MGC803 cells, which harbored mutant p53. Pifithrin- $\alpha$, a p53 inhibitor, blocked the modulation of $\mathrm{As}_{4} \mathrm{~S}_{4}$ on AGS cells, but not on MGC803 cells. Using xenograft as a model, we showed that $\mathrm{As}_{4} \mathrm{~S}_{4}$ suppressed tumor growth and induced apoptosis in vivo and that the expression of p53 increased accordingly.

Conclusion: $\mathrm{As}_{4} \mathrm{~S}_{4}$ is a potent cytotoxic agent for gastric cancer cells, as it induced apoptosis both in vitro and in vivo through a p53-dependent pathway. Our data indicate that $\mathrm{As}_{4} \mathrm{~S}_{4}$ may have therapeutic potential in gastric cancer.

Keywords: $\mathrm{As}_{4} \mathrm{~S}_{4}, \mathrm{p} 53$, realgar, antitumor, xenograft

\section{Introduction}

Gastric cancer is the fourth most common malignant tumor worldwide. ${ }^{1}$ According to "Cancer Statistics, 2014", 2 approximately 22,220 new gastric cases are diagnosed annually, resulting in 10,990 deaths in the United States. In Asia, gastric cancer is the third most common cancer after breast and lung cancer, and the second most common cause of cancer death after lung cancer. There are more than 677,000 cases of gastric cancer annually in the developing countries, and one-half of the world total occurs in Eastern Asia, mainly in the People's Republic of China. ${ }^{3,4}$ Although radical surgery for patients diagnosed at early stages can prolong overall survival, the high recurrence rate is still a major problem. Even though first-line chemotherapies have been proven to prolong overall survival and improve quality of life compared with supportive care, the 5-year survival rate in patients with advanced gastric cancer who 
receive palliative chemotherapy is barely $5 \%$ to $10 \%{ }^{5,6}$ Therefore, a new strategy for the treatment of gastric cancer is urgently needed.

Arsenic compounds have been used for more than 2,400 years as traditional Chinese medicines and have attracted much research attention in recent years. ${ }^{7,8}$ There are three main types of mineral arsenical: arsenolite (mainly $\mathrm{As}_{2} \mathrm{O}_{3}$, arsenic trioxide), realgar (mainly $\mathrm{As}_{4} \mathrm{~S}_{4}$, tetraarsenic tetrasulfide), and orpiment (mainly $\mathrm{As}_{2} \mathrm{~S}_{3}$, arsenic trisulfide). $\mathrm{As}_{2} \mathrm{O}_{3}$ has had excellent therapeutic impact in the treatment of acute promyelocytic leukemia (APL). ${ }^{9-12}$ Recently, $\mathrm{As}_{4} \mathrm{~S}_{4}$, the main component of realgar, has gained more focus due to its advantages of oral administration, relative safety, and ample resources. ${ }^{13} \mathrm{As}_{4} \mathrm{~S}_{4}$ has antitumor activities in several cancers, especially APL, in vitro and in vivo, ${ }^{14-18}$ and the antitumor activities are correlated with its ability to inhibit cell proliferation and induce apoptosis. ${ }^{19-21}$

p53 is a critical gatekeeper against oncogenesis and malignant cell proliferation. Mutations in the p53 gene are the most common genetic abnormality, and approximately $50 \%$ of human cancers contain p53 mutation. ${ }^{22-24}$ Wild-type p53 gene transfer enhances cytotoxicity of anticancer drugs in human cancer cells in vitro and in vivo. ${ }^{25,26}$ The crucial tumor suppressor activity of p53 involves both transcriptiondependent and -independent mechanisms. Several studies have found that the state of p53 plays an important role in the process of drug-induced apoptosis of tumor cells..$^{27-29}$

In previous studies, we explored the anticancer effect and mechanism of $\mathrm{As}_{4} \mathrm{~S}_{4}$ on a series of solid tumor cell lines, such as MKN45 cells (gastric cancer), HepG2 cells (hepatocellular carcinoma), A375 cells (malignant melanoma), and 8898 cells (pancreatic carcinoma), and showed that $\mathrm{As}_{4} \mathrm{~S}_{4}$ possessed potent antitumor activities in solid tumors and induced apoptosis. ${ }^{18,30}$ To further investigate the cytotoxic effect and the molecular mechanism of $\mathrm{As}_{4} \mathrm{~S}_{4}$ in gastric cancer and whether or not p53 is important in mediating the effect of $\mathrm{As}_{4} \mathrm{~S}_{4}$, we selected the wild-type p53 containing AGS cells and the mutant p53 containing MGC803 cells. ${ }^{31,32} \mathrm{We}$ found that $\mathrm{As}_{4} \mathrm{~S}_{4}$ exerted potent antiapoptotic and cytotoxic effects in both cell lines; however, the effect of arsenic on the AGS cells was much more pronounced than on the MGC803 cells, indicating that p53 played a critical role in the process of $\mathrm{As}_{4} \mathrm{~S}_{4}$ induced apoptosis of gastric cancer cells. Using p53 inhibitor pifithrin- $\alpha$, we found that the cytotoxic effect was blocked only in the AGS cells, but not in MGC803. These findings provide evidence that $\mathrm{p} 53$ is a critical factor in mediating cytotoxic effects of $\mathrm{As}_{4} \mathrm{~S}_{4}$ in gastric cancer cells.

\section{Materials and methods}

\section{Chemicals, solutions, and antibodies}

Highly purified realgar supplied by the Shanghai Institute of Hematology (Shanghai, People's Republic of China) was prepared from mined natural realgar. The purity of $\mathrm{As}_{4} \mathrm{~S}_{4}$ in our realgar preparation was greater than $98.0 \%$, confirmed by repeated X-ray powder diffraction analyses (in collaboration with the Research Center at the Xi'an Institute of Geology and Mineral Resources [Xi'an, People's Republic of China]). These results were compatible with pure $\mathrm{As}_{4} \mathrm{~S}_{4}$ standards and excluded the potential for trace amounts of arsenic trioxide and other arsenic compounds that could influence the results. The high-purity realgar was dissolved in Dulbecco's phosphate-buffered saline (DPBS) (Thermo Fisher Scientific, Waltham, MA, USA) and sterilized by filtration. The content of As in DPBS solution was determined by inductively coupled plasma atomic emission spectrometry at the Instrumental Analysis Center of Shanghai Jiao Tong University (Shanghai, People's Republic of China). An $\mathrm{As}_{4} \mathrm{~S}_{4}$ stock solution of $277.2496 \mu \mathrm{M}$ was stored at $4^{\circ} \mathrm{C}$. According to the blood arsenic levels from $\mathrm{As}_{4} \mathrm{~S}_{4}-$ treated patients, the stock solution was appropriately diluted between 100 and 1,000 times in DPBS to obtain a working solution. Anti-p53, anti-Bcl-2, and anti-Bax antibodies were purchased from Cell Signaling Technology ([CST], Beverly, MA, USA). Anti-MDM2 antibody, pifithrin- $\alpha$, MTT, and sodium dodecyl sulfate (SDS) powder were purchased from Sigma-Aldrich Co. (St Louis, MO, USA). $\beta$-actin antibody was purchased from Proteintech Group, Inc (Wuhan, Hubei, People's Republic of China). MTT powder was dissolved in DPBS at the concentration of $5 \mathrm{mg} / \mathrm{mL}$. SDS powder was dissolved in water at the concentration of $10 \%$.

\section{Cells and cell culture}

The human gastric adenocarcinoma cell line AGS (harboring wild-type p53) and MGC803 (harboring mutant p53) were obtained from Cell Bank, Chinese Academy of Sciences (Shanghai, People's Republic of China). The human gastric epithelial cell line (also known as GES-1) was purchased from Beijing ComWin Biotech Co. Ltd. (Beijing, People's Republic of China). AGS cells were cultured in DMEM/F-12 1:1 medium (Thermo Fisher Scientific), and MGC803 and GES-1 cells were cultured in RPMI 1640 medium (Thermo Fisher Scientific). All media were supplemented with 10\% fetal bovine serum, $100 \mathrm{U} / \mathrm{mL}$ penicillin, and $100 \mu \mathrm{g} / \mathrm{mL}$ streptomycin (Thermo Fisher Scientific). All cells were cultured at $37^{\circ} \mathrm{C}$ under an atmosphere of $95 \%$ air and $5 \% \mathrm{CO}_{2}$. 


\section{Cell viability assay}

The effect of $\mathrm{As}_{4} \mathrm{~S}_{4}$ on AGS, MGC803, and GES-1 cell proliferation was measured using MTT assay. The MTT assay was performed as previously described. ${ }^{19}$ with minor modifications according to the manufacturer's protocol. Cells were seeded in 96-well plates at a density of $5 \times 10^{3}$ cells/well and incubated overnight, then treated with different concentrations of $\mathrm{As}_{4} \mathrm{~S}_{4}$ for 24, 48, or 72 hours, respectively. At the end of the exposure period, $10 \mu \mathrm{L}$ MTT solutions were added to each well and cells were incubated at $37^{\circ} \mathrm{C}$ for 4 hours. Following the 4 hours' incubation, $150 \mu \mathrm{L}$ SDS solutions ( $10 \%$ concentration) were added to each well to dissolve the formazan at $37^{\circ} \mathrm{C}$ overnight. Absorbance of each sample was measured at $570 \mathrm{~nm}$. Data were analyzed based on three independent experiments.

\section{4',6-diamidino-2-phenylindole staining}

4',6-diamidino-2-phenylindole (DAPI) staining was used to observe the morphology changes of the nuclei of gastric cancer cells treated with $\mathrm{As}_{4} \mathrm{~S}_{4}$. Cells were seeded at $5 \times 10^{4}$ cells/well in 24-well plates and incubated overnight, then treated with $1.25 \mu \mathrm{M}$ of $\mathrm{As}_{4} \mathrm{~S}_{4}$ for 0,24 , or 48 hours, respectively. Then, the supernatant was aspirated, and DAPI (Beyotime Institute of Biotechnology, Haimen, Jiangsu, People's Republic of China) was added to each well for 5 minutes. DAPI-stained cell morphology was observed under a fluorescence microscope (DMI 3000B; Leica Microsystems, Wetzlar, Germany).

\section{Annexin V-fluorescein isothiocyanate/ propidium iodide staining}

Annexin V-fluorescein isothiocyanate (FITC)/propidium iodide (PI) double staining was used to quantify the apoptotic rate of human gastric cancer cells treated with $\mathrm{As}_{4} \mathrm{~S}_{4}$. Cells were seeded at $1 \times 10^{6}$ cells $/$ dish in $10 \mathrm{~cm}$ dishes and incubated overnight, then treated with different concentrations of $\mathrm{As}_{4} \mathrm{~S}_{4}$ $(0 \mu \mathrm{M}, 1.25 \mu \mathrm{M}, 2.5 \mu \mathrm{M})$ for 24 hours. The cells were then harvested and stained with annexin V-FITC/PI (Vazyme Biotech Co. Ltd., Nanjing, Jiangsu, People's Republic of China) following the manufacturer's instructions. After incubation for 30 minutes at $4^{\circ} \mathrm{C}$, the cells were analyzed using flow cytometry (FACS Canto; BD Biosciences, Franklin Lakes, NJ, USA).

\section{Western blotting analysis}

Total protein from the cells or the tumor specimens of animals was extracted using radioimmunoprecipitation assay lysis buffer (Beyotime Institute of Biotechnology). Protein concentrations were analyzed using a bicinchoninic acid protein assay kit (Beyotime Institute of Biotechnology) according to the manufacturer's protocol. The Western blotting analysis was performed as previously described ${ }^{33}$ with minor modifications according to the manufacturer's protocol. Equal amounts of proteins $(60 \mu \mathrm{g})$ were loaded, separated by SDS polyacrylamide gel electrophoresis gels, and transferred onto the polyvinylidene fluoride membrane (Millipore, Darmstadt, Germany). The membrane was incubated with specific primary antibodies $(1: 1,000)$ at $4^{\circ} \mathrm{C}$ overnight after blocking nonspecific binding sites with 5\% nonfat milk. After washing thrice in Tris-buffered saline and Tween 20 for 10 minutes each time, membranes were incubated with goat anti-mouse or anti-rat antibody labeled with horseradish peroxidase (Beyotime Institute of Biotechnology) for 1 hour at room temperature. Proteins were detected with an enhanced chemiluminescence system using the Beyo ECL Plus kit (Beyotime Institute of Biotechnology) and were semi-quantified using Image J software.

\section{Real-time polymerase chain reaction analysis}

Total RNA was extracted using TRIzol (Takara, Japan), and reverse transcription and polymerase chain reaction (PCR) amplification were carried out with a reverse transcriptase kit (Takara) according to the manufacturer's protocol. The primer sequences for targeted genes as well as GAPDH are listed in Table 1. Real-time PCR was performed using the ABI PRISM 7500 System (Thermo Fisher Scientific). The comparative cycle threshold (CT) $\left(2^{-\Delta \Delta C T}\right)$ method was used to determine the relative concentration.

\section{Animals and tumor models}

Twenty-eight 4-week-old male BALB/C-nu/nu mice weighing 17-20 g were purchased from Shanghai Laboratory Animal Research Center (Shanghai, People's Republic of

Table I Primer sequences for real-time polymerase chain reaction

\begin{tabular}{ll}
\hline Gene & Primer sequence $\left(\mathbf{5}^{\prime}-\mathbf{3}^{\prime}\right)$ \\
\hline Bax & F: aagctgagcgagtgtctcaag \\
& R: caaagtagaaagggcgacaac \\
Bcl-2 & F: gtttgatttctcctggctgtctc \\
& R: gaaccttttgcatatttgtttgg \\
p53 & F: ggtaatctactgggacggaacagc \\
& R: attctccatccagtggtttcttctt \\
MDM2 & F: cattgaaccttgtgtgatttgtc \\
& R: gcagggcttattccttttctt ta \\
GAPDH & F: ggcacagtcaaggctgagaatg \\
& R: atggtggtgaagacgccagta \\
\hline
\end{tabular}

Abbreviations: $F$, forward; $R$, reverse. 
China). Mice were acclimatized for 1 week at the Animal Laboratory Centre of Tongji University, Shanghai, People's Republic of China before any interventions were initiated. Xenograft tumor models were established by implanting MGC803 gastric cancer cells $\left(5 \times 10^{6}\right.$ cells/mouse in $200 \mu \mathrm{L}$ RPMI 1640 medium) subcutaneously. The mice were kept under pathogen-free conditions in a laminar flow cabinet air filter at a constant temperature of $22^{\circ} \mathrm{C} \pm 2{ }^{\circ} \mathrm{C}, 55 \% \pm 5 \%$ relative humidity, and a 12 -hour dark/light cycle. Food and water were allowed ad libitum. All experiments were performed in accordance with the guidelines of the laboratory animal handling protocols of Tongji University.

\section{In vivo treatment}

At day 7 after tumor inoculation, when established tumors of 0.2 to $0.3 \mathrm{~cm}^{3}$ in diameter were detectable, drug administration was begun. The animals were randomly divided into four groups consisting of seven animals each: 1) blank control group (normal saline [NS] $20 \mathrm{~mL} / \mathrm{kg}$ ); 2) positive control group (cyclophosphamide [CTX], $25 \mathrm{mg}$ / $\mathrm{kg}$ in $0.4 \mathrm{~mL})$; 3) low-dose group $\left(\mathrm{As}_{4} \mathrm{~S}_{4}, 1 \mathrm{mg} / \mathrm{kg}\right.$ in 0.4 $\mathrm{mL})$; and 4) high-dose group $\left(\mathrm{As}_{4} \mathrm{~S}_{4}, 2 \mathrm{mg} / \mathrm{kg}\right.$ in $\left.0.4 \mathrm{~mL}\right)$. The method of injection was a once-a-day intraperitoneal injection for 3 weeks. The weight of the mice and tumor size were measured every other day. The mice were sacrificed after treatment for 3 weeks.

\section{Evaluation of tumor growth}

Tumor volumes were calculated according to the following formula:

$$
\left(\text { length } \times \text { width }^{2}\right) / 2 \text {. }
$$

The therapeutic efficacy of the xenografts were assessed using the tumor growth inhibition (TGI), which was calculated according to the following formula:

$$
\left(1-\mathrm{W}_{\mathrm{t}} / \mathrm{W}_{\mathrm{c}}\right) \times 100 \%
$$

where $\mathrm{W}_{\mathrm{t}}$ is the mean tumor weight of the treated group and $\mathrm{W}_{\mathrm{c}}$ is the mean tumor weight of the control group.

\section{Hematoxylin and eosin staining}

The tumor tissues from mice were fixed with $10 \%$ buffered formalin for 24 hours, and then embedded in paraffinum, sectioned at a thickness of $3 \mathrm{~mm}$. Tissue slides were stained with Ehrlich hematoxylin and eosin (Beyotime Institute of Biotechnology) followed by dehydration in graded alcohol. Slides were observed and analyzed using a light microscope.

\section{TdT-mediated dUTP nick end labeling assay}

Detection of apoptosis was performed using a TdT-mediated dUTP nick end labeling (TUNEL) assay kit, which was purchased from R\&D Systems, Inc. (Minneapolis, $\mathrm{MN}, \mathrm{USA})$. Tissue slides were treated with proteinase $\mathrm{K}(20 \mu \mathrm{g} / \mathrm{mL})$ for 15 minutes at room temperature, and then rinsed three times with phosphate-buffered saline (PBS) for 3 minutes each time. Slides were placed in PBS which containing $3 \% \mathrm{H}_{2} \mathrm{O}_{2}$, incubated for 10 minutes to block endogenous peroxidase activity. After rinsing in PBS, tissues were incubated in TdT reaction buffer for 10 minutes. The slides were then incubated with TdT reaction mixture for 1 hour at $37^{\circ} \mathrm{C}$, blocked with stop/wash buffer for 10 minutes, and incubated with streptavidin-horseradish peroxidase in PBS for 30 minutes at room temperature to detect the labeled DNA fragments. Finally, slides were incubated with DAB, and counterstained with hematoxylin.

\section{Immunohistochemistry}

The expression of p53 was analyzed in paraffin-embedded sections obtained from mouse tumors. The slides were deparaffinized, rehydrated, and antigen was retrieved. After blocking nonspecific proteins with bovine serum albumin, slides were incubated with mouse polyclonal antibodies against p53 (1:500; CST) overnight at $4^{\circ} \mathrm{C}$. Horseradish peroxidaselabeled anti-mouse IgG and DAB (BOSTER, Wuhan, Hubei, People's Republic of China) were incubated to visualize the p53 antibody at room temperature. Five separate fields were randomly selected in each slide and the average proportion of p53-positive cells were assessed in each field.

\section{Statistical analysis}

Statistical analysis was performed using SPSS software (v 13.0; SPSS Inc, Chicago, IL, USA). All data were expressed as mean \pm standard deviation (SD). Data were analyzed using one-way analysis of variance, followed by either the least significant difference procedure (if variance was equal) or the Games-Howell procedure (if variance was unequal). A twosided $P<0.05$ was considered statistically significant.

\section{Results}

\section{The cytotoxicity of $\mathrm{As}_{4} \mathrm{~S}_{4}$ against different cell lines}

AGS, MGC803, and GES-1 cells were treated with different concentrations of $\mathrm{As}_{4} \mathrm{~S}_{4}(0.00,0.31,0.62,1.25,2.50,5.00$, 
$10.00 \mu \mathrm{M})$ for 24 hours. The half-maximal inhibitory concentration values (24 hours) of $\mathrm{As}_{4} \mathrm{~S}_{4}$ for AGS, MGC803, and GES-1 cells were $2.69,3.26$, and $6.27 \mu \mathrm{M}$, respectively (Figure 1A), indicating that the wild-type p53-containing AGS cells were more sensitive to $\mathrm{As}_{4} \mathrm{~S}_{4}$ than the mutant $\mathrm{p} 53$ containing MGC803 cells. Furthermore, these gastric cancer cells were more sensitive to $\mathrm{As}_{4} \mathrm{~S}_{4}$ than the human gastric epithelium cells. Then, gastric cancer cells were treated with different concentrations of $\mathrm{As}_{4} \mathrm{~S}_{4}(0.00,0.31,0.62,1.25,2.50$, $5.00,10.00 \mu \mathrm{M})$ for 24,48 , or 72 hours, respectively. Results showed that $\mathrm{As}_{4} \mathrm{~S}_{4}$ inhibited the proliferation of gastric cancer cells in a time- and dose-dependent manner between $0.31 \mu \mathrm{M}$ and $10.00 \mu \mathrm{M}$ concentrations (Figure $1 \mathrm{~B}$ and $\mathrm{C}$ ).

\section{Apoptosis of gastric cancer cells treated with $\mathrm{As}_{4} \mathrm{~S}_{4}$}

To assess the morphological change induced by $\mathrm{As}_{4} \mathrm{~S}_{4}$, the gastric cancer cells were stained with DAPI and observed under a fluorescence microscope. After being treated with $\mathrm{As}_{4} \mathrm{~S}_{4}(1.25 \mu \mathrm{M})$ for 24 hours, AGS and MGC803 cells revealed nuclear chromatin condensation to the edge, which is similar to the morphological changes observed in cells undergoing apoptosis, while the control cells exhibited intact and normal nuclei in morphology. Furthermore, AGS and MGC803 cells treated for 48 hours appeared to be in advanced phases of degradation, with disassembled and fragmented nuclei (Figure 2A).

\section{Quantification of apoptosis rate using annexin V-FITC/PI staining}

The apoptotic cells were assessed by flow cytometry using annexin V-FITC/PI staining. After treatment of AGS cells for 24 hours, $1.25 \mu \mathrm{M} \mathrm{As}_{4} \mathrm{~S}_{4}$ resulted in approximately $6.73 \%$ of the cells had reached the early apoptotic phase (annexin V-positive, PI-negative staining) $(P<0.01)$. With an increased concentration of $\mathrm{As}_{4} \mathrm{~S}_{4}$, ie, $2.50 \mu \mathrm{M}, 23.10 \%$ of the cells entered the early apoptotic phase $(P<0.001)$ (Figure 2B). For MGC803 cells, the exposure to $2.50 \mu \mathrm{M} \mathrm{As}_{4} \mathrm{~S}_{4}$ for 24 hours resulted in $11.48 \%$ of the cells entering the early apoptotic phase $(P<0.001) . \mathrm{As}_{4} \mathrm{~S}_{4}$ induced a greater apoptosis ratio in AGS cells than that induced in MGC803 cells (Figure 2B). Data represented the mean \pm $\mathrm{SD}$ of three independent experiments.
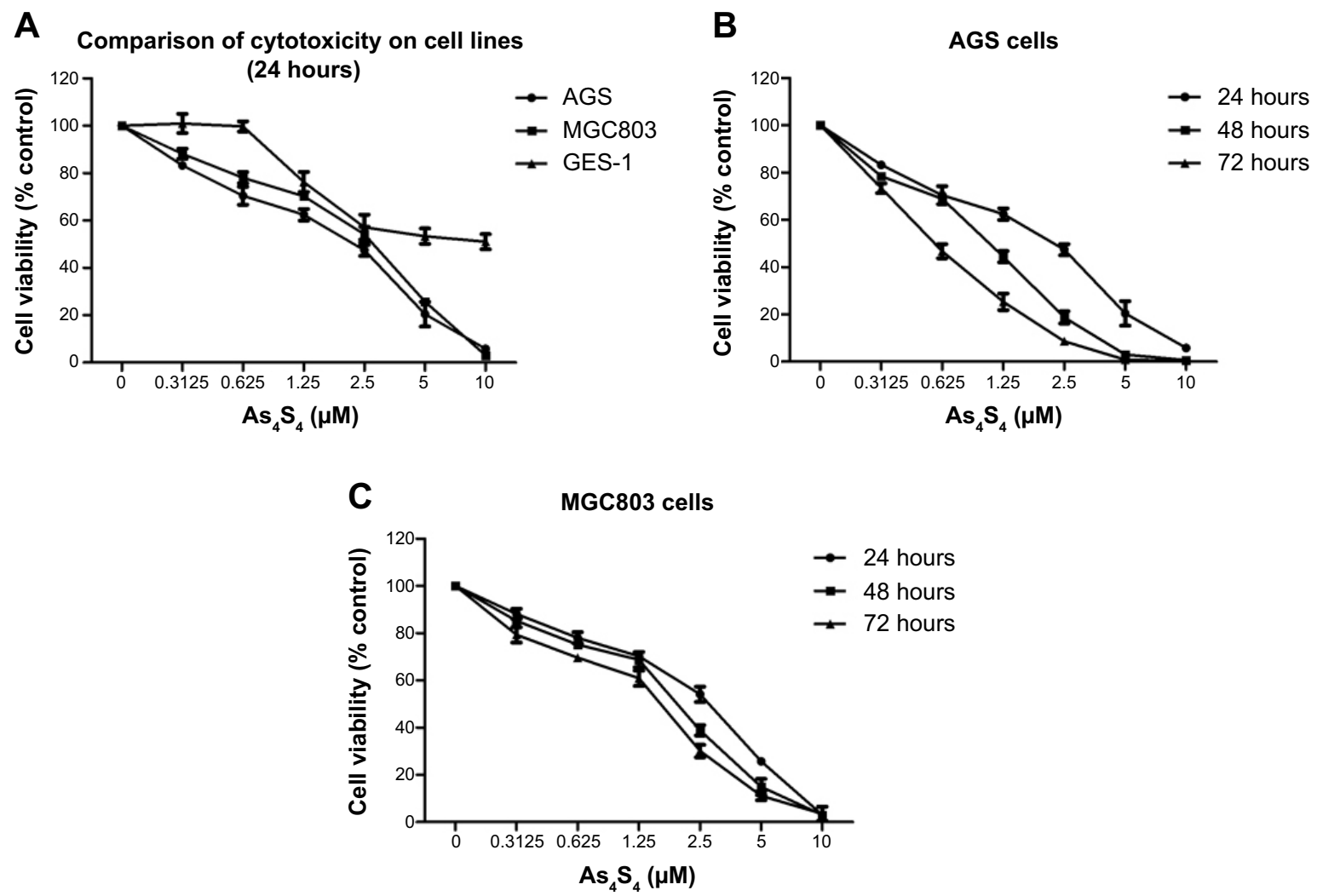

Figure I Curves of cell viability in gastric cancer cells treated with $\mathrm{As}_{4} \mathrm{~S}_{4}$.

Notes: (A) The cytotoxicity of $\mathrm{As}_{4} \mathrm{~S}_{4}$ against different cell lines. The comparisons of cytotoxicity of $\mathrm{As}_{4} \mathrm{~S}_{4}$ against AGS, MGC803, and GES-I cells when treated for 24 hours. The half-maximal inhibitory concentration values of $\mathrm{As}_{4} \mathrm{~S}_{4}$ against AGS, MGC803, and GES-I cells were 2.69, 3.26, and 6.27 $\mu$ M, respectively. (B) Dose- and time-dependent curves of cell viability in AGS cells treated with $\mathrm{As}_{4} \mathrm{~S}_{4}$. (C) Dose- and time-dependent curves of cell viability in MGC803 cells treated with $\mathrm{As}_{4} \mathrm{~S}_{4}$. Data represent the mean \pm standard deviation of three independent experiments. 
A

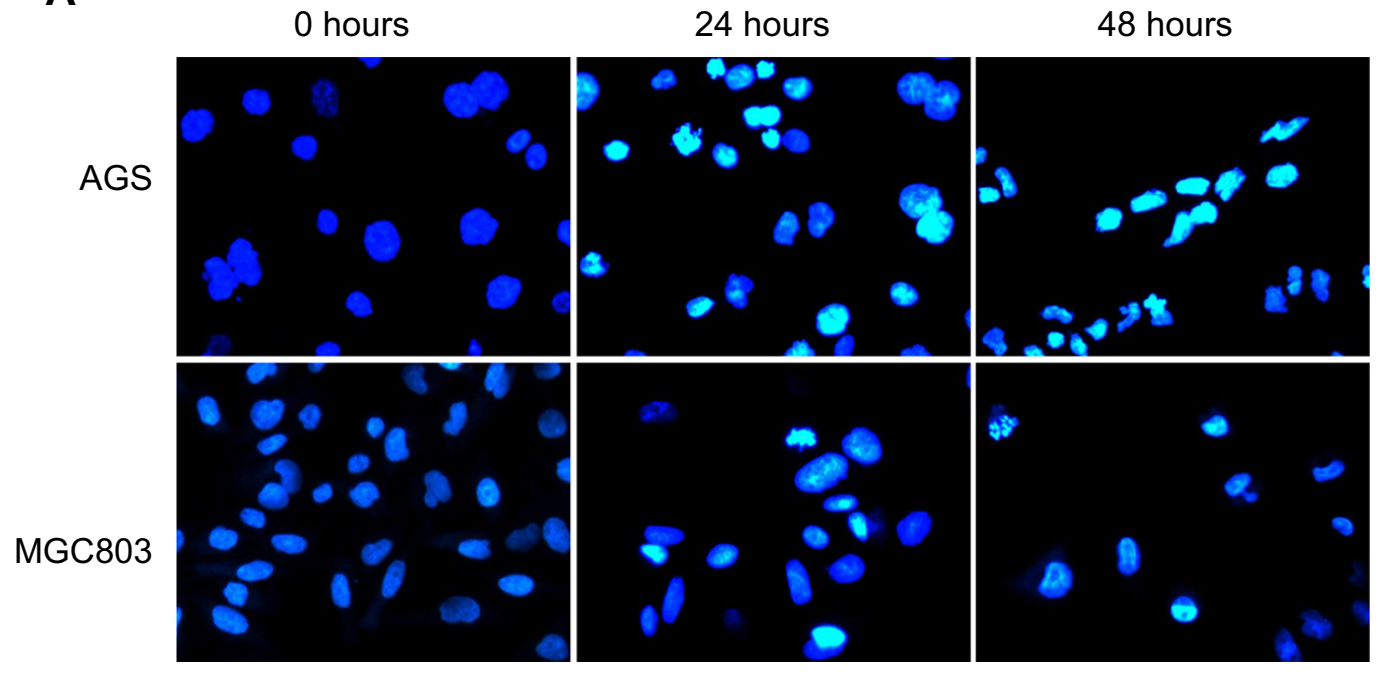

B
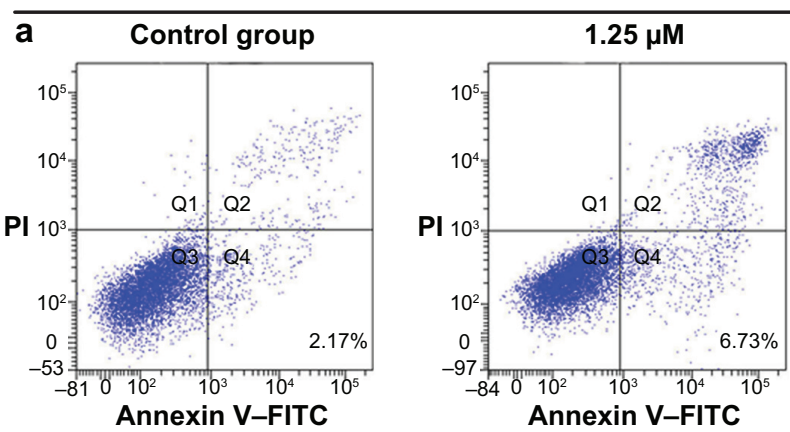

AGS cells
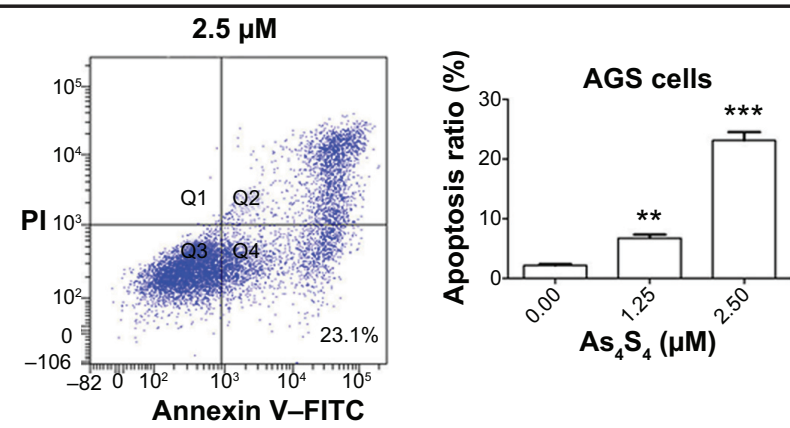

MGC803 cells
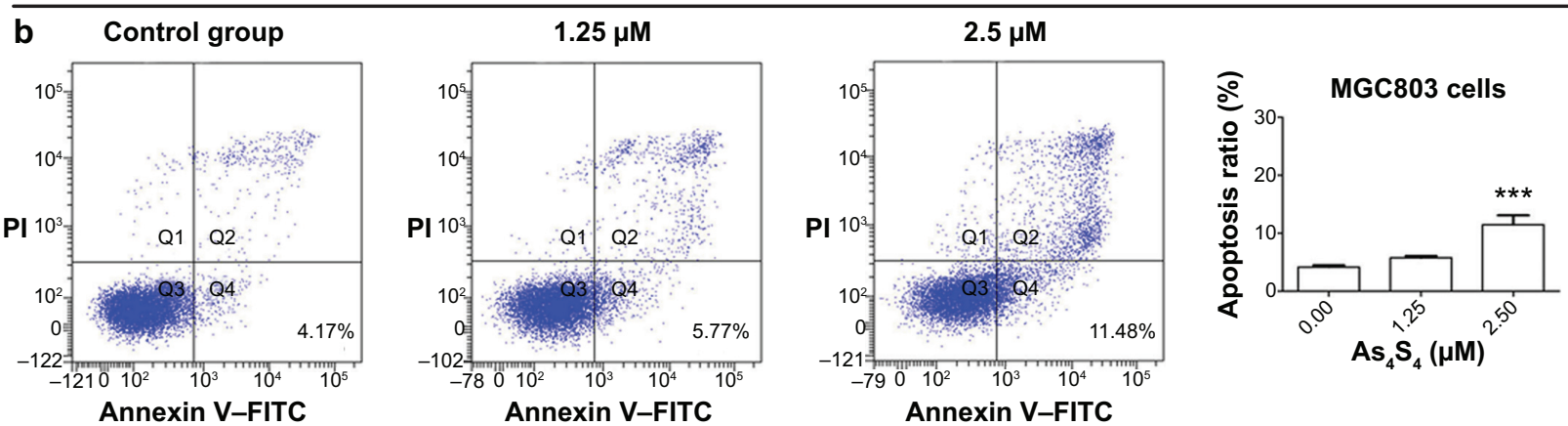

Figure 2 Arsenic sulfide-induced apoptosis of gastric cancer cells.

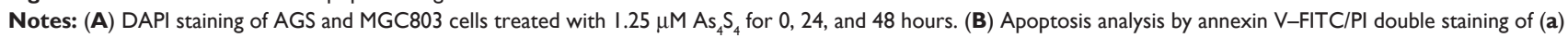
AGS and (b) MGC803 cells treated with $\mathrm{As}_{4} \mathrm{~S}_{4}(0 \mu \mathrm{M}, \mathrm{I} .25 \mu \mathrm{M}, 2.5 \mu \mathrm{M})$ for 24 hours. Apoptosis ratios represent the percent of cells in the early apoptosis stage (PI-negative/ annexin V-FITC-positive). Data represent the mean \pm standard deviation of three independent experiments. $* * P<0.0 \mathrm{I} ; * * * P<0.00 \mathrm{I}$.

Abbreviations: DAPI, 4',6-diamidino-2-phenylindole; FITC, fluorescein isothiocyanate; PI, propidium iodide; Q, quadrant.

\section{Changes in expression of the apoptotic} and antiapoptotic proteins induced

\section{by $\mathrm{As}_{4} \mathrm{~S}_{4}$}

In the AGS cells, Western blotting analysis showed that $\mathrm{As}_{4} \mathrm{~S}_{4^{-}}$ induced apoptosis and reduction in cell viability was correlated with upregulation of p53 protein levels (Figure 3 ). However, real-time PCR analysis showed no significant changes in the p53 mRNA levels (Figure 4). This suggests that $\mathrm{As}_{4} \mathrm{~S}_{4}$ increased the protein stability of $\mathrm{p} 53$, rather than affecting the expression of its RNA level. The proapoptotic protein Bax is one of the critical downstream mediators in p53 signaling pathways. Both the mRNA and the protein level of Bax were increased, as shown in Figures 3 and 4, while the protein level of Bcl-2 was significantly reduced when treated with 

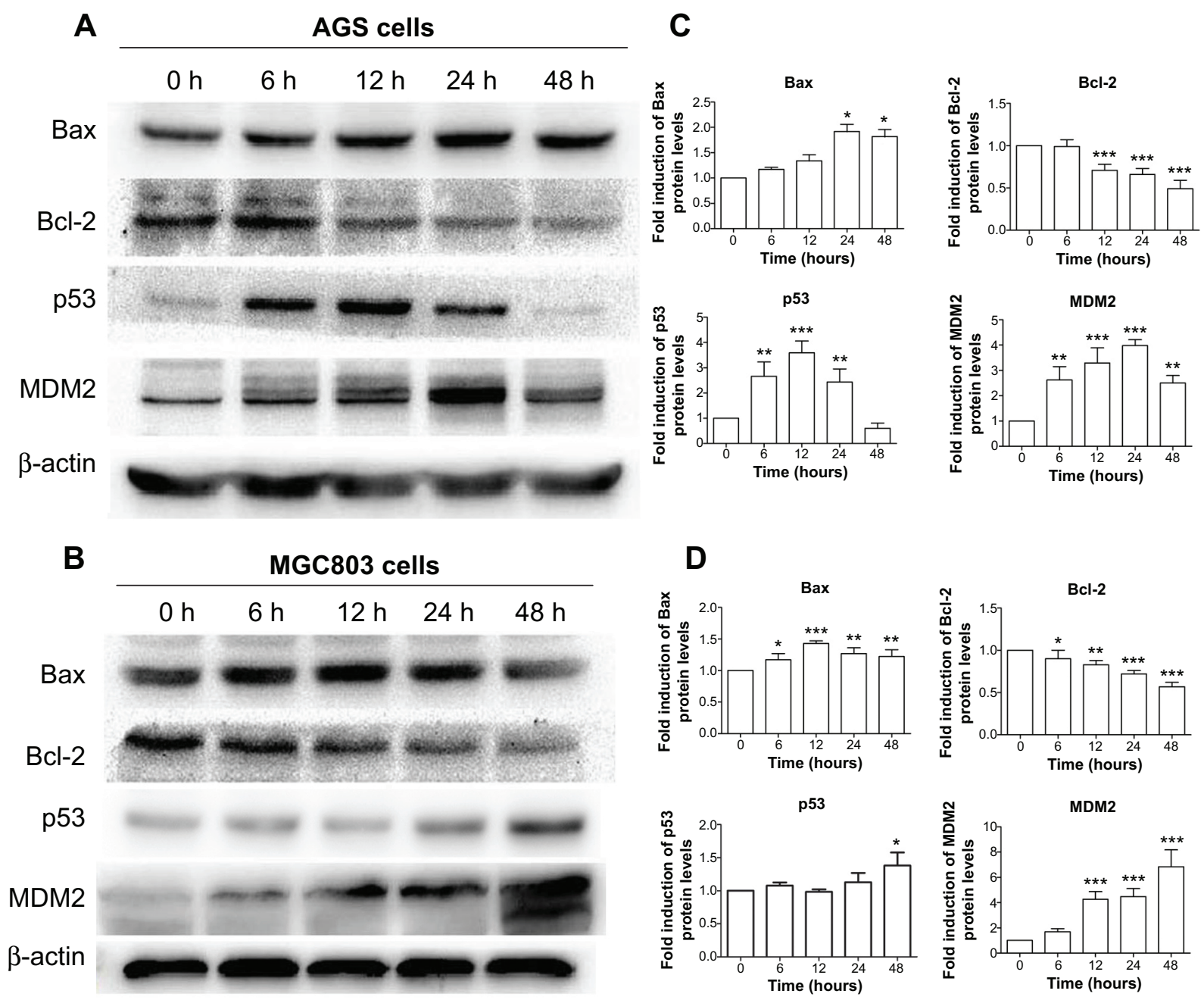

Figure 3 Western blotting results of AGS and MGC803 cells treated with I.25 $\mu \mathrm{MAs} \mathrm{As}_{4}$ for 0, 6, I2, 24, and 48 hours.

Notes: Time-dependent regulation by $\mathrm{As}_{4} \mathrm{~S}_{4}$ in (A) AGS cells and (B) MGC803 cells. Cells were treated with $\mathrm{As}_{4} \mathrm{~S}_{4}(\mathrm{I} .25 \mu \mathrm{M})$ for $0,6,12,24$, or 48 hours. The data are representative of at least three independent experiments. (C and D) Protein quantification of the Western blot results shown in $(\mathbf{A})$ and $(\mathbf{B})$, respectively. Protein levels were normalized to the $\beta$-actin levels and are shown as fold increase or decrease relative to the levels for the control strain. $* P<0.05$; $* * P<0.01 ; * * * P<0.00$ I.

$\mathrm{As}_{4} \mathrm{~S}_{4}$ (Figure 3). The expression of MDM2 was upregulated and peaked at 24 hours after the treatment with $\mathrm{As}_{4} \mathrm{~S}_{4}$. This is consistent with $\mathrm{p} 53$ protein degradation accelerating 24 hours after the treatment with $\mathrm{As}_{4} \mathrm{~S}_{4}$ and its level dropping to below the control level after 48 hours. In the p53 mutant-containing MGC803 cells, the upregulation of Bax protein was still observed, but at a much lower level, while downregulation of Bcl-2 protein was equally apparent compared to the AGS cells. The expression of mutant p53 was elevated at 48 hours, however, increased expression of MDM2 was observed at 6 hours and peaked at 48 hours (Figure 3).

\section{$\mathrm{As}_{4} \mathrm{~S}_{4}$ induce $\mathrm{p} 53$ transcription-dependent apoptosis in AGS cells}

Pifithrin- $\alpha$ was used to determine the role of the p53 transcription-dependent pathway in the growth inhibition and apoptosis induction induced by $\mathrm{As}_{4} \mathrm{~S}_{4}$. Pifithrin- $\alpha$ is a small molecule that binds to the DNA-binding domain of p53, thereby inhibiting its transcriptional activities. AGS and MGC803 cells were pretreated with $30 \mu \mathrm{M}$ pifithrin- $\alpha$ (a concentration that does not cause significant cytotoxicity in these cells) for 30 minutes prior to addition of $\mathrm{As}_{4} \mathrm{~S}_{4}$. MTT and Western blotting analysis showed that pretreatment with pifithrin- $\alpha$ suppressed $\mathrm{As}_{4} \mathrm{~S}_{4}$-induced cytotoxicity within a certain range $(\leq 1.25 \mu \mathrm{M})$ (Figure $5 \mathrm{~A})$ and partially restored the protein levels of $\mathrm{p} 53$, MDM2, Bax, and Bcl-2 in the wildtype p53-containing AGS cells (Figure 5B and C), but did not show a protective effect on the mutant $\mathrm{p} 53$-containing MGC803 cells. Pifithrin- $\alpha$ alone did not modify p53, Bax, Bcl-2, or MDM2 expressions in the AGS cells compared with untreated control cells. These data indicate that $\mathrm{p} 53$ transcription-dependent pathway plays an important role 
A

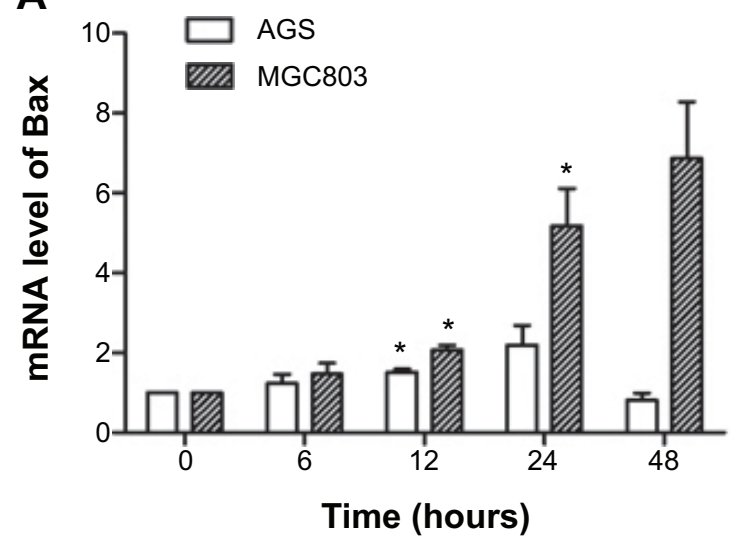

C

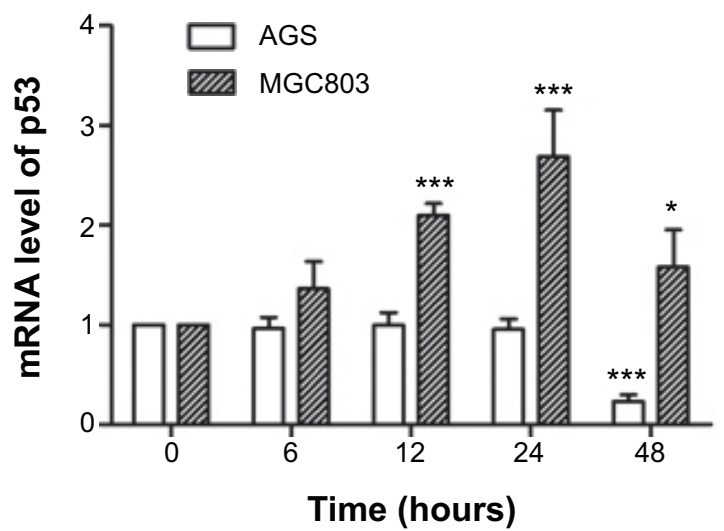

B
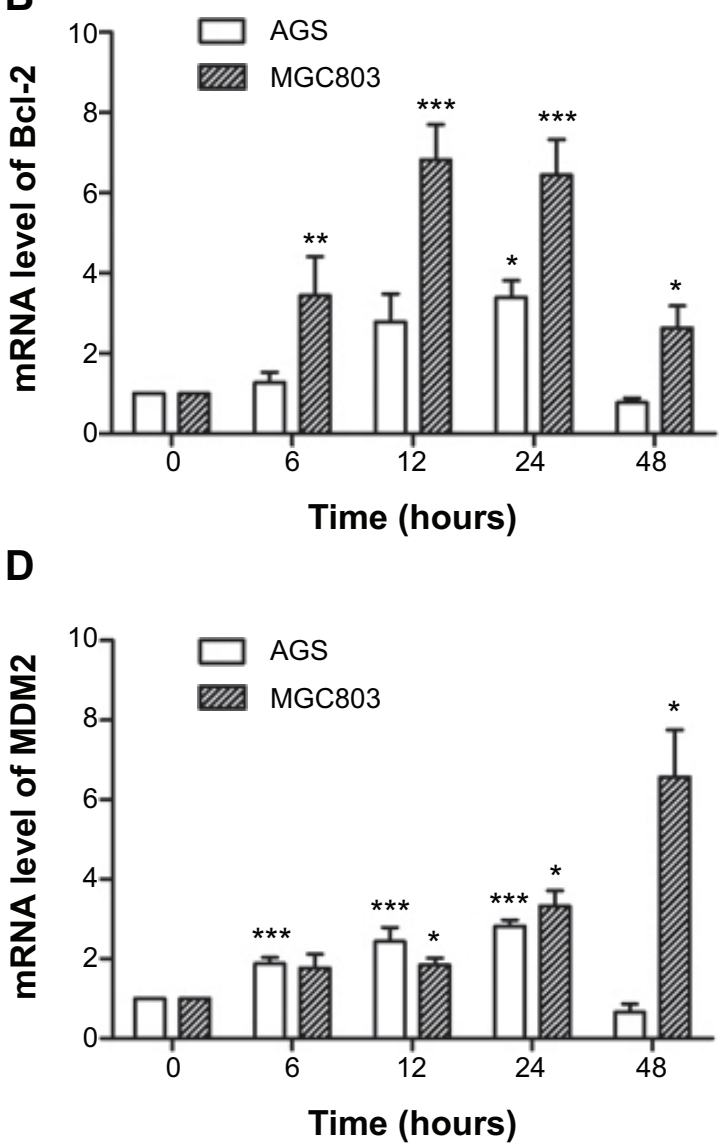

Figure 4 Relative expressions of mRNA levels of Bax, Bcl-2, p53, and MDM2 in AGS and MGC803 cells.

Notes: (A) mRNA levels of Bax. (B) mRNA levels of Bcl-2. (C) mRNA levels of p53. (D) mRNA levels of MDM2. The cells were treated with As $\mathrm{S}_{4}$ (I.25 $\mu$ M) for 0, 6, I2, 24 , or 48 hours. Relative expressions of mRNA were determined by relative quantification real-time polymerase chain reaction. RNA levels (normalized to GAPDH RNA levels) were represented as fold increase or decrease relative to the levels for the control strain. Data are expressed as means \pm standard deviations of three independent experiments. $* P<0.05 ; * * P<0.01 ; * * * P<0.001$.

in $\mathrm{As}_{4} \mathrm{~S}_{4}$-induced growth inhibition and apoptosis in the AGS cells.

\section{$\mathrm{As}_{4} \mathrm{~S}_{4}$ inhibited the growth of gastric cancer in vivo}

In order to determine the effect of $\mathrm{As}_{4} \mathrm{~S}_{4}$ in gastric cancer, we conducted experiments in vivo. For the in vivo study, there were no significant differences in the tumor volumes among the four groups before the start of the drug treatment $(P>0.05)$. After treatment for 3 weeks, we found that the tumor size and weight in the groups treated with $\mathrm{As}_{4} \mathrm{~S}_{4}$ were significantly reduced compared with the blank control group $(P<0.05$, Figure $6 \mathrm{~A}-\mathrm{C})$. Interestingly, we found that $\mathrm{As}_{4} \mathrm{~S}_{4}$ at a low dose $(1 \mathrm{mg} / \mathrm{kg})$ was more effective than at higher doses in tumor suppression (Figure 6C). TGI in the positive control group (CTX, $25 \mathrm{mg} / \mathrm{kg}$ ), lowdose group $\left(\mathrm{As}_{4} \mathrm{~S}_{4}, 1 \mathrm{mg} / \mathrm{kg}\right)$, and high-dose group $\left(\mathrm{As}_{4} \mathrm{~S}_{4}, 2\right.$ $\mathrm{mg} / \mathrm{kg}$ ) was $52.81 \%, 38.01 \%$, and $26.79 \%$, respectively. The test for heterogeneity of tumor weights in each group was not significant $(P>0.05)$. While conducting the experiment, we found that the toxic effects of $\mathrm{As}_{4} \mathrm{~S}_{4}$ in mice were not apparent, as the differences in body weights between each group were not significant (Figure 6D). No unexpected death of mice was observed throughout the experiment.

\section{$\mathrm{As}_{4} \mathrm{~S}_{4}$ changed the histological structure of tumor in xenograft mice}

The histological changes of the tumors were observed under a light microscope after hematoxylin and eosin staining. The tumor cells in the control group were densely packed, while the tumor cells were much less dense in the $\mathrm{As}_{4} \mathrm{~S}_{4}$-treated group. This significant reduction of the number of tumor cells was accompanied by nuclear condensation and reduction of the nuclear-cytoplasmic ratio. In the $\mathrm{As}_{4} \mathrm{~S}_{4}$ treatment groups, we observed significantly increased necrotic cells as well as increased inflammatory cells surrounding the tumors (Figure 7A). 


\section{A Protective effect of PFT- $\alpha$ on AGS cells (24 hours)}
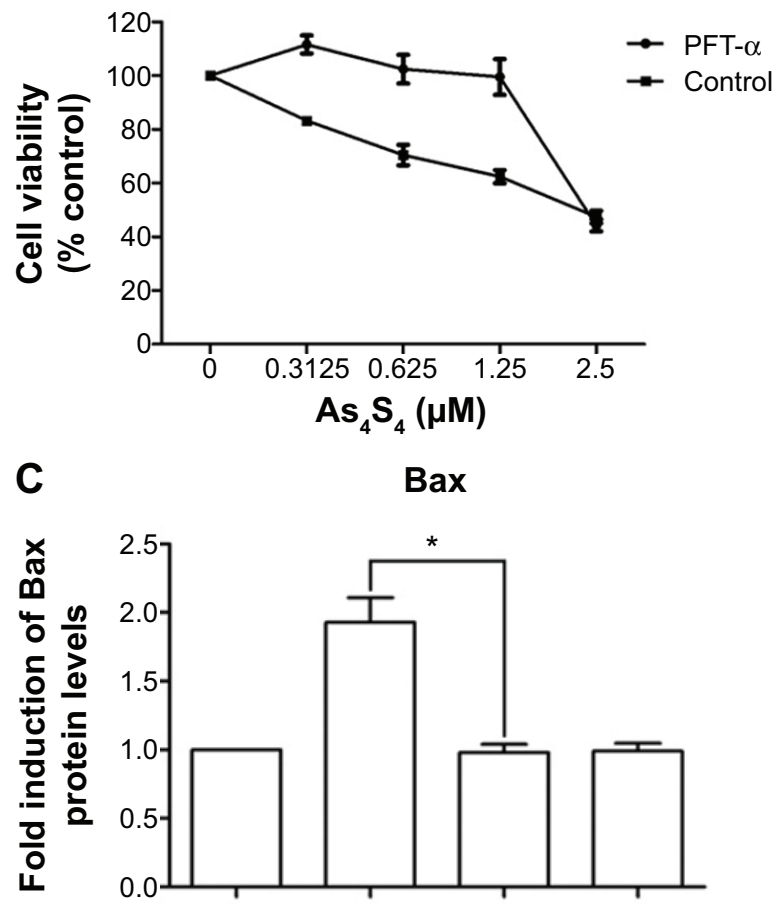

C

$\mathrm{As}_{4} \mathrm{~S}_{4}$

PFT- $\alpha$

Bax
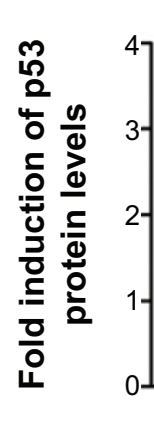

p53

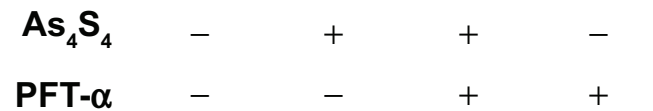

B

\section{AGS cells}

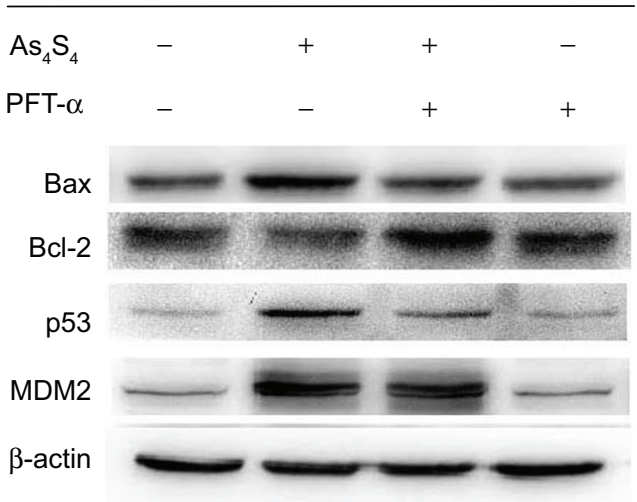

$\mathrm{Bcl}-2$

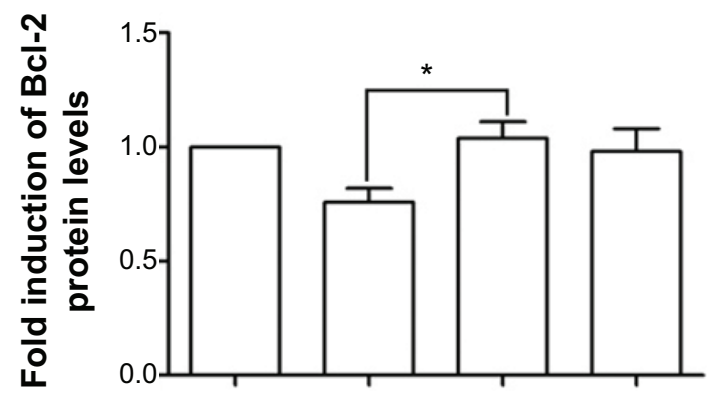

$\mathrm{As}_{4} \mathrm{~S}_{4}$

PFT- $\alpha$

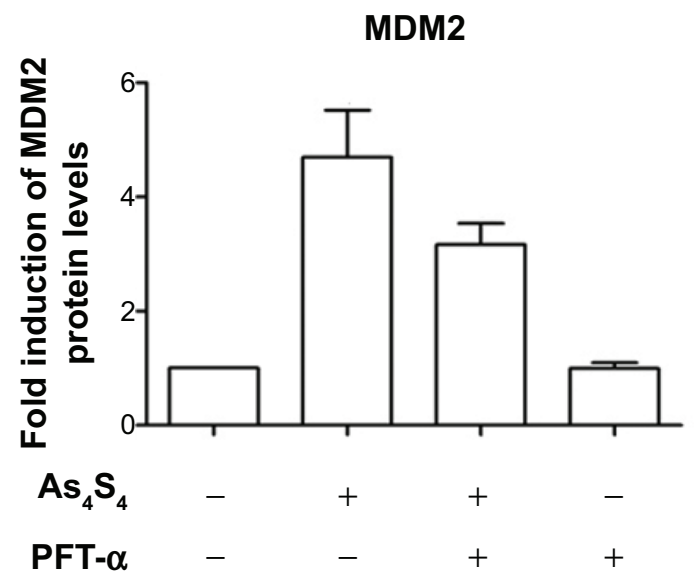

Figure 5 Effect of pifithrin- $\alpha$ (PFT- $\alpha)$ on $\mathrm{As}_{4} \mathrm{~S}_{4}$-treated AGS cells.

Notes: (A) The cell viability of AGS cells when treated with different concentrations of $\mathrm{As}_{4} \mathrm{~S}_{4}$ for 24 hours in the presence or absence of $30 \mu \mathrm{M}$ PFT- $\alpha$. Data represent the mean \pm standard deviation of three independent experiments. (B) AGS cells were pretreated with $30 \mu M$ PFT- $\alpha$ for 30 minutes prior to addition of I.25 $\mu$ M As $\mathrm{S}_{4}$, then cells were cultured for another 24 hours. (C) Protein quantification of the Western blot results shown in (B). Protein levels were normalized to the $\beta$-actin levels and are shown as fold increase or decrease relative to the levels for the control strain. $* P<0.05$; $* * * P<0.001$.

\section{$\mathrm{As}_{4} \mathrm{~S}_{4}$ induces apoptosis in xenograft mice}

TUNEL assay has been designed to detect the doublestranded DNA fragmentation of apoptotic cells undergoing extensive DNA degradation during the late stages of apoptosis. As shown in Figure 7B and $\mathrm{C}$, the percentage of TUNEL-positive cells (stained in yellow) in the group treated with $\mathrm{As}_{4} \mathrm{~S}_{4}$ was higher than in the blank control group $(P<0.05)$, which suggests that $\mathrm{As}_{4} \mathrm{~S}_{4}$ induces apoptosis of gastric cancer cells and inhibits proliferation. 


\section{A}

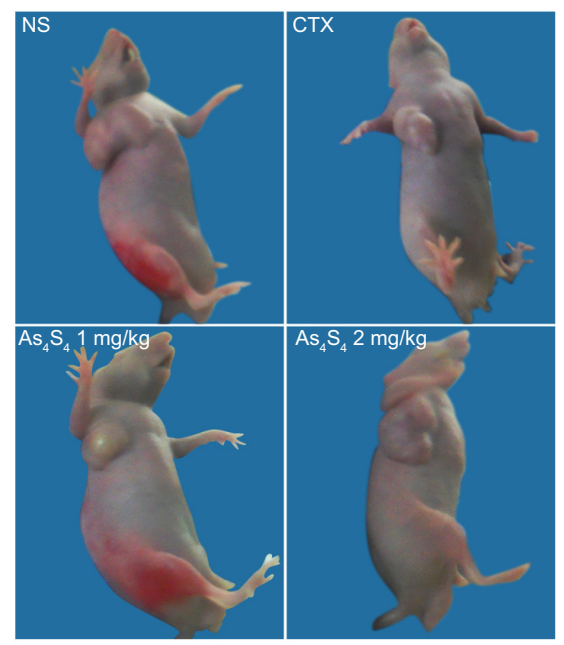

B

$\mathrm{As}_{4} \mathrm{~S}_{4} 1 \mathrm{mg} / \mathrm{kg}$

$\mathrm{As}_{4} \mathrm{~S}_{4} 2 \mathrm{mg} / \mathrm{kg}$

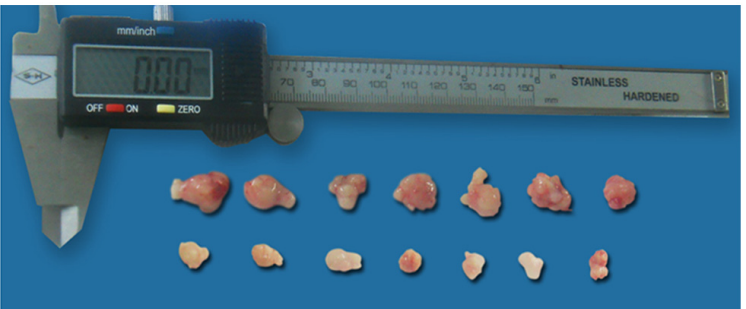

00000

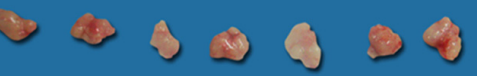

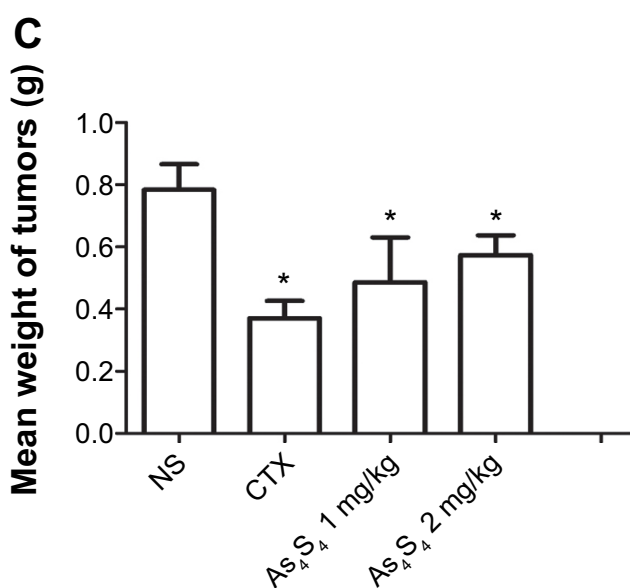

D

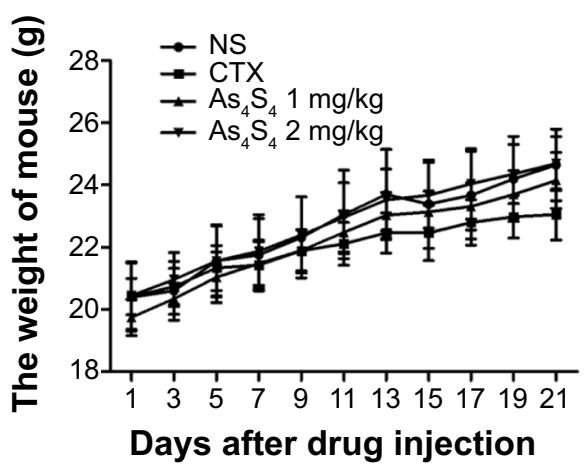

Figure $6 \mathrm{As}_{4} \mathrm{~S}_{4}$ inhibited tumor growth and induced apoptosis in gastric cancer xenograft mice.

Notes: (A) Representative photograph of mice in each group taken 21 days after treatment. (B) Effect of $\mathrm{As}_{4} \mathrm{~S}_{4}$ on tumor growth in gastric cancer xenograft mice. (C) The mean weight of tumors in nude mice at the time of sacrifice. Data shown are means with standard deviations of the tumor weight from seven individual mice in each group. $* P<0.05$. (D) Mean weights of mice were measured every other day.

Abbreviations: CTX, cyclophosphamide; NS, normal saline.

\section{$\mathrm{As}_{4} \mathrm{~S}_{4}$ regulates the expression of $\mathrm{p} 53$ in xenograft mice}

We examined the effect of $\mathrm{As}_{4} \mathrm{~S}_{4}$ on the expression of $\mathrm{p} 53$ in vivo using a xenograft model. As shown in Figure 7D and $\mathrm{E}$, the expression of p53 was significantly increased after treatment with $\mathrm{As}_{4} \mathrm{~S}_{4}$. By immunohistochemical staining of xenograft tumor tissues, we found that the percentage of $\mathrm{p} 53$-positive tumor cells in the $\mathrm{As}_{4} \mathrm{~S}_{4}$ treated mice $(26.22 \% \pm 3.14 \%)$ was much higher than in the control group $(1.43 \% \pm 1.37 \%)(P<0.001)$ (Figure $7 \mathrm{~F}$ and $\mathrm{G})$. This result is consistent with that of the Western blotting.

\section{Discussion}

$\mathrm{As}_{4} \mathrm{~S}_{4}$, an arsenic compound, has shown antitumor activities in malignancies, especially in APL, with limited toxicities. ${ }^{14-18}$ The molecular mechanism of its antitumor activity is related to its ability to induce apoptosis ${ }^{19,21,34,35}$ and the redistribution of PML-RAR $\alpha$ protein in the leukemic cells. ${ }^{20}$

Much less is known about $\mathrm{As}_{4} \mathrm{~S}_{4}$ in gastric cancer. In our study, $\mathrm{As}_{4} \mathrm{~S}_{4}$ inhibited the proliferation of both AGS and MGC803 cells while showing minor toxicity to normal human gastric mucosa tissues. $\mathrm{As}_{4} \mathrm{~S}_{4}$ reduced the viability of the gastric cancer cells in a time- and dose-dependent manner, and the wild-type p53-containing AGS cells was more sensitive to $\mathrm{As}_{4} \mathrm{~S}_{4}$ than the mutant p53-containing MGC803 cells. These data suggest that $\mathrm{p} 53$ is a critical protein in $\mathrm{As}_{4} \mathrm{~S}_{4}-$ induced cytotoxicity in gastric cancer cells. Therefore, we investigated further the relationship between the antitumor activities of $\mathrm{As}_{4} \mathrm{~S}_{4}$ in gastric cancer cells and the changes of p53 expression.

As a tumor suppressor gene, p53 functions as a transcription factor and stimulates the expression of many apoptotic effectors, such as PUMA, NOXA, BID, Bax, and 

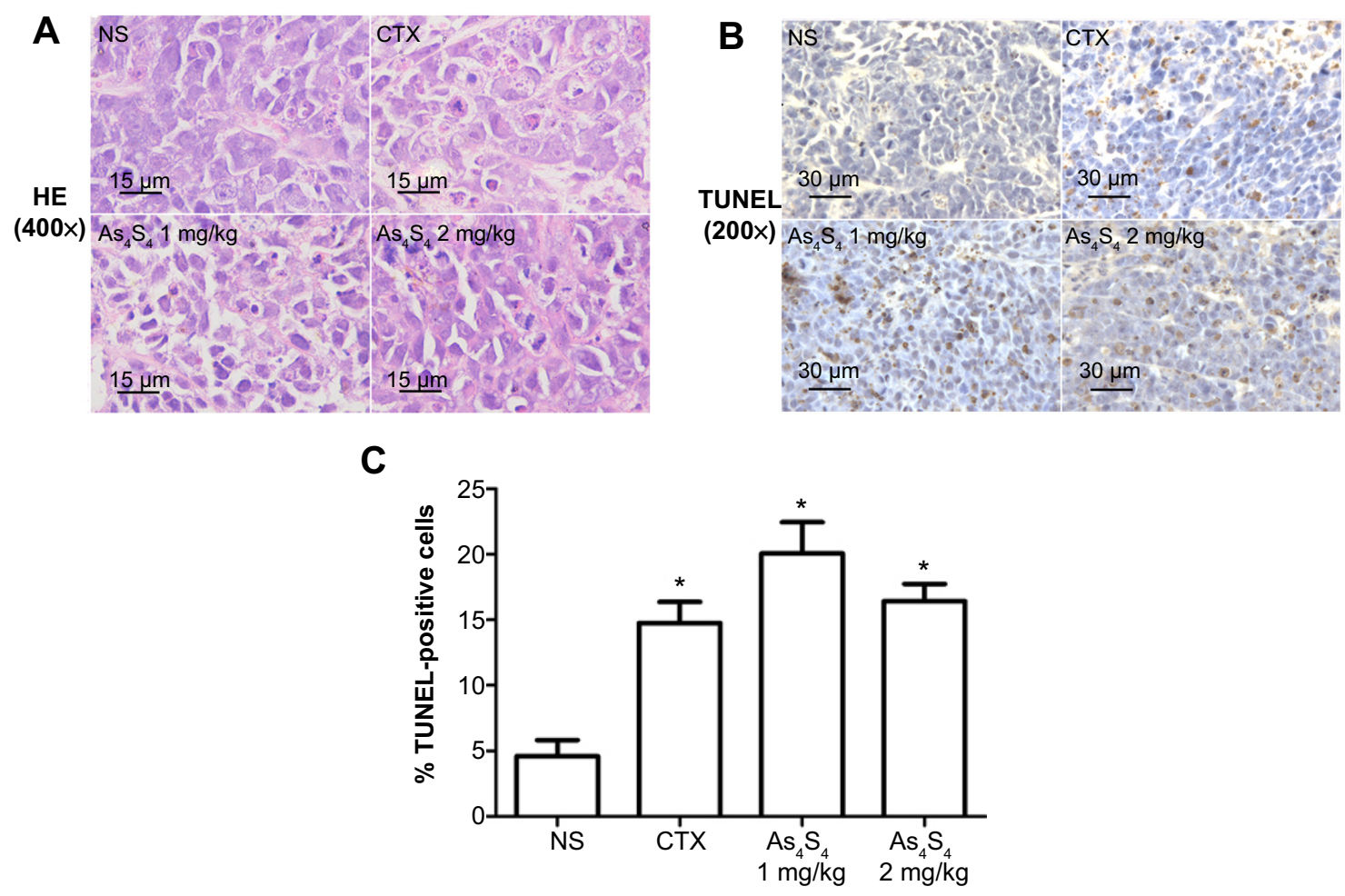

D

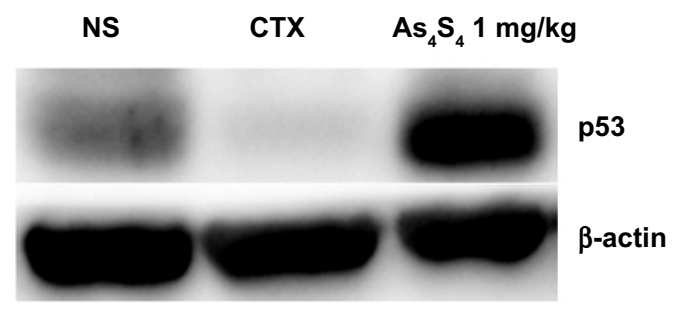

$\mathbf{F}$

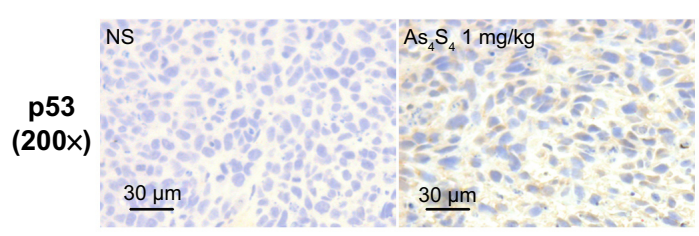

E

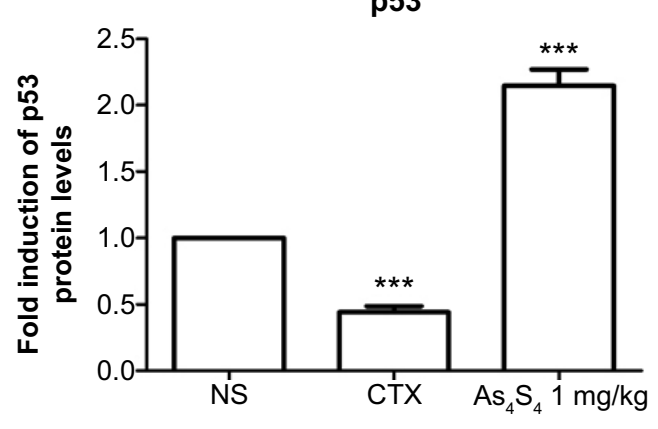

G

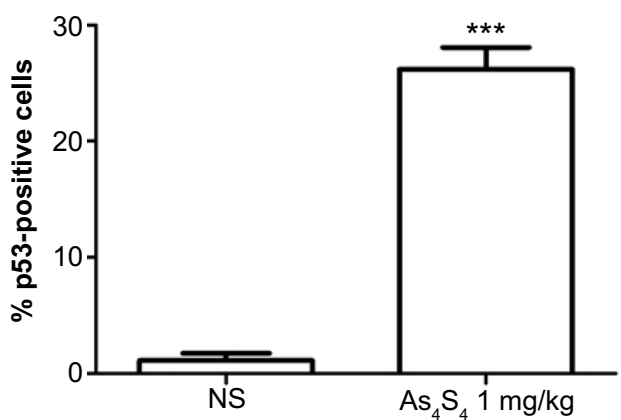

Figure 7 Effect of $\mathrm{As}_{4} \mathrm{~S}_{4}$ on the structural changes, cell apoptosis, and expression of p53 protein in xenograft mice.

Notes: (A) Detection of structural changes by HE staining under a light microscope at a magnification of 400X. (B) Detection of apoptotic cells by TUNEL under a light microscope at a magnification of 200x. (C) The percentage of TUNEL-positive cells. (D) Total protein from the tumor was extracted, and the expression of $\mathrm{p} 53$ protein was detected by Western blotting. (E) Integrated density of p53 protein, shown relative to the control. (F) The expression of p53 in tumor tissues was detected by immunohistochemical assay under a light microscope at a magnification of 200×. (G) Quantification of immunohistochemical assay is represented as percentage of positively stained cells. Data shown are mean \pm standard deviation. $* P<0.05 ; * * *<0.00$ I.

Abbreviations: CTX, cyclophosphamide; HE, hematoxylin and eosin; NS, normal saline; TUNEL, TdT-mediated dUTP nick end labeling. 
p53AIP1 proteins. ${ }^{36,37}$ p53 can also transcriptionally repress the expression of antiapoptotic proteins, such as Bcl-2, Bcl-XL, and survivin. ${ }^{38,39}$ In our study, apoptosis induction was confirmed by DAPI and annexin V-FITC/PI staining. Gastric cancer cells treated with $\mathrm{As}_{4} \mathrm{~S}_{4}$ exhibited condensed and fragmented nuclei, which is a hallmark of apoptosis. Furthermore, quantitative analysis of the apoptosis ratio indicated that the percentage of cells in early apoptosis stage was increased after treatment with $\mathrm{As}_{4} \mathrm{~S}_{4}$. These findings indicate that cytotoxicity induced by $\mathrm{As}_{4} \mathrm{~S}_{4}$ involves the induction of apoptosis.

$\mathrm{As}_{4} \mathrm{~S}_{4}$ treatment remarkably increased the p53 expression levels in a time-dependent pattern in the AGS cells. As expected, the increased p53 protein level was correlated with the upregulation of its downstream target gene Bax and the downregulation of Bcl-2. Such an effect likely forms the basis for the induction of apoptosis of AGS cells. These findings are consistent with the previous results reported by Guo et $\mathrm{al}^{40}$ wherein $\mathrm{As}_{4} \mathrm{~S}_{4}$ induced the apoptosis of SGC7901 cells by regulating the expression of Bcl-2 and Bax. Importantly, we found that the p53-specific transcriptional inhibitor pifithrin- $\alpha$ could partially reverse the effect of $\mathrm{As}_{4} \mathrm{~S}_{4}$ on the AGS cell proliferation. Moreover, blocking the activation of $\mathrm{p} 53$ by pifithrin- $\alpha$ could partially restore the protein levels of p53, Bax, and Bcl-2. Interestingly, in the annexin V-FITC/PI staining, we found that exposure to concentrations up to $2.50 \mu \mathrm{M}$ resulted in more early apoptotic cells, while pifithrin- $\alpha$ only showed a protective effect within a certain dose range of $\mathrm{As}_{4} \mathrm{~S}_{4}(\leq 1.25 \mu \mathrm{M})$. This low-dose protective effect may indicate that other apoptotic pathways also play a role in the apoptosis induced by the higher concentration of $\mathrm{As}_{4} \mathrm{~S}_{4}(\geq 2.5 \mu \mathrm{M})$ in AGS cells. Additionally, the protective effect that occurred at this low-dose level of $\mathrm{As}_{4} \mathrm{~S}_{4}$ may suggest a competitive binding mechanism, by which other factors that competitively bind to p53 may occupy the pifithrin- $\alpha$ binding sites and prevent the effects of pifithrin- $\alpha$.

It has been reported that wild-type p53 protein is kept at a low level in cells by the proteasome degradation pathway under unstressed conditions, while mutant $\mathrm{p} 53$ protein usually accumulates to a high level in malignant cells. ${ }^{41,42}$ However, we found that the level of the mutant p53 in MGC803 cells was low in our study, and that treatment with $\mathrm{As}_{4} \mathrm{~S}_{4}$ did not readily influence the expression of the mutant p53 in MGC803 cells, as there was no significant change in the levels of p53 protein until 48 hours. The mechanism of this delayed upregulation of $\mathrm{p} 53$ protein is unclear, and needs to be further explored. In our study, $\mathrm{As}_{4} \mathrm{~S}_{4}$ was found to trigger apoptosis through the upregulation of Bax/Bcl-2 protein ratio, independent of p53 expression in the MGC803 cells. Furthermore, pifithrin- $\alpha$ did not show a protective effect in the MGC803 cells. These results indicate that short-duration treatment with $\mathrm{As}_{4} \mathrm{~S}_{4}$ stimulated apoptosis in MGC803 cells, likely by increasing the $\mathrm{Bax} / \mathrm{Bcl}-2$ ratio and bypassing $\mathrm{p} 53$.

Real-time PCR analysis showed that AGS cells treated with $\mathrm{As}_{4} \mathrm{~S}_{4}$ showed no significant changes in the p53 mRNA levels when compared to the untreated control group. Thus, how $\mathrm{As}_{4} \mathrm{~S}_{4}$ upregulated p53 protein is still not completely clear. We postulate that $\mathrm{As}_{4} \mathrm{~S}_{4}$ upregulates p53 protein through downregulating the expression of the MDM2 protein levels. MDM2, an E3 ubiquitin ligase, is a critical feedback regulator of $\mathrm{p} 53$. The transcription of the MDM2 is induced by the p53 protein activation after DNA damage, and then the MDM2 protein binds to p53 and blocks its activities and promotes its degradation. High levels of MDM2 protein promote polyubiquitination and subsequent proteasomedependent degradation of p53. ${ }^{43}$

In the present study, p53 and MDM2 protein levels were upregulated as early as 6 hours after treatment with $1.25 \mu \mathrm{M}$ $\mathrm{As}_{4} \mathrm{~S}_{4}$ in AGS cells. With the upregulation of MDM2 protein levels, p53 degradation started to accelerate at 24 hours (Figure 3). These findings concealed the feedback loop between p53 and MDM2 proteins. The transcription of the MDM2 was induced by the $\mathrm{p} 53$ protein activation after treatment with $\mathrm{As}_{4} \mathrm{~S}_{4}$, and then the MDM2 protein promoted the degradation of $\mathrm{p} 53$ protein. But how $\mathrm{As}_{4} \mathrm{~S}_{4}$ upregulated the p53 protein remains unclear. Due to the critical inhibitory effect of MDM2 on p53, targeting the interaction of MDM2 with p53 is a potential cancer therapeutic strategy. Therefore, combination treatment with $\mathrm{As}_{4} \mathrm{~S}_{4}$ and small molecular-based approaches which target the p53-MDM2 axis may enhance the cytotoxicity of $\mathrm{As}_{4} \mathrm{~S}_{4}$ in AGS cells.

In this study, we also assessed the effects of $\mathrm{As}_{4} \mathrm{~S}_{4}$ in inducing apoptosis in gastric cancer in the xenograft nude mice. In the selection of tumor cells, we chose MGC803 cells rather than AGS cells because we found that AGS cells did not form tumor structures under the subcutaneous tumor model we established. By calculating the TGI and using immunohistochemical staining for TUNEL, we found that $\mathrm{As}_{4} \mathrm{~S}_{4}$ induced apoptosis and inhibited proliferation in tumor tissues. In addition, the results of Western blotting and immunohistochemistry in vivo showed that $\mathrm{As}_{4} \mathrm{~S}_{4}$ upregulated the expression of p53 in xenograft mice, which further confirms the inference that $\mathrm{As}_{4} \mathrm{~S}_{4}$ induces apoptosis in a p53-dependent manner. Interestingly, there were a higher TGI and more 
apoptotic cells in the low-dose group $\left(\mathrm{As}_{4} \mathrm{~S}_{4}, 1 \mathrm{mg} / \mathrm{kg}\right)$ than in the high-dose group $\left(\mathrm{As}_{4} \mathrm{~S}_{4}, 2 \mathrm{mg} / \mathrm{kg}\right)$, which suggests that the capabilities of $\mathrm{As}_{4} \mathrm{~S}_{4}$ to induce apoptosis and inhibit proliferation were associated with the drug dose, however, the exact relationship still needs to be further elucidated.

\section{Conclusion}

The present study indicates that $\mathrm{As}_{4} \mathrm{~S}_{4}$ can effectively inhibit gastric cancer cell proliferation by inducing apoptosis both in vitro and in vivo through a p53-dependent pathway. Our understanding of the mechanism by which $\mathrm{As}_{4} \mathrm{~S}_{4}$ activates p53 remains incomplete and needs to be further explored. Our data demonstrate that $\mathrm{As}_{4} \mathrm{~S}_{4}$ is a potent cytotoxic agent for gastric cancer cells and may have therapeutic potential.

\section{Acknowledgments}

This work was supported by the National Natural Science Foundation of China (81274142, 30300139), the Natural Science Foundation of Science and Technology Commission of Shanghai Municipality (11ZR1423400), and the Key Project of Shanghai Municipal Education Commission (07zz43).

\section{Disclosure}

The authors report no conflicts of interest in this work.

\section{References}

1. Jemal A, Bray F, Center MM, Ferlay J, Ward E, Forman D. Global cancer statistics. CA Cancer J Clin. 2011;61(2):69-90.

2. Siegel R, Ma J, Zou Z, Jemal A. Cancer statistics, 2014. CA Cancer J Clin. 2014;64(1):9-29

3. Rahman R, Asombang AW, Ibdah JA. Characteristics of gastric cancer in Asia. World J Gastroenterol. 2014;20(16):4483-4490.

4. GLOBOCAN 2012: estimated cancer incidence, mortality and prevalence worldwide in 2012 [homepage on the Internet]. Lyon: International Agency for Research on Cancer. Available from: http:// globocan.iarc.fr/Pages/fact_sheets_cancer.aspx. Accessed September 27, 2014.

5. Qiu MZ, Xu RH. The progress of targeted therapy in advanced gastric cancer. Biomark Res. 2013;1(1):32.

6. Wagner AD, Grothe W, Haerting J, Kleber G, Grothey A, Fleig WE. Chemotherapy in advanced gastric cancer: a systematic review and meta-analysis based on aggregate data. J Clin Oncol. 2006;24(18):2903-2909.

7. Wang ZY. Arsenic compounds as anticancer agents. Cancer Chemother Pharmacol. 2001;48 Suppl 1:S72-S76.

8. Prajapati V, Kale RK, Singh RP. Arsenic and its combinations in cancer therapeutics. Ther Deliv. 2011;2(6):793-806.

9. Chen GQ, Zhu J, Shi XG, et al. In vitro studies on cellular and molecular mechanisms of arsenic trioxide $\left(\mathrm{As}_{2} \mathrm{O}_{3}\right)$ in the treatment of acute promyelocytic leukemia: $\mathrm{As}_{2} \mathrm{O}_{3}$ induces NB4 cell apoptosis with downregulation of Bcl-2 expression and modulation of PML-RAR alpha/PML proteins. Blood. 1996;88(3):1052-1061.

10. Shen $Z X$, Chen GQ, Ni JH, et al. Use of arsenic trioxide $\left(\mathrm{As}_{2} \mathrm{O}_{3}\right)$ in the treatment of acute promyelocytic leukemia (APL): II. Clinical efficacy and pharmacokinetics in relapsed patients. Blood. 1997; 89(9):3354-3360.
11. Niu C, Yan H, Yu T, et al. Studies on treatment of acute promyelocytic leukemia with arsenic trioxide: remission induction, follow-up, and molecular monitoring in 11 newly diagnosed and 47 relapsed acute promyelocytic leukemia patients. Blood. 1999;94(10):3315-3324.

12. Sanz MA, Fenaux P, Lo Coco F; European APL Group of Experts. Arsenic trioxide in the treatment of acute promyelocytic leukemia. A review of current evidence. Haematologica. 2005;90(9):1231-1235.

13. Hughes MF. Arsenic toxicity and potential mechanisms of action. Toxicol Lett. 2002;133(1):1-16.

14. Lu DP, Qiu JY, Jiang B, et al. Tetra-arsenic tetra-sulfide for the treatment of acute promyelocytic leukemia: a pilot report. Blood. 2002; 99(9):3136-3143.

15. Chen SY, Liu SX, Li XM. In vitro study on arsenic sulfide (realgar)-induced apoptosis of retinoic acid susceptible or resistant acute promyelocytic leukemia cell lines. J Med Coll PLA. 2002; 17(1):43-47.

16. Baláž P, Sedlák J. Arsenic in cancer treatment: challenges for application of realgar nanoparticles (a minireview). Toxins (Basel). 2010;2(6):1568-1581.

17. Zhao Y, Wen G, Qiao Z, et al. Effects of tetra-arsenic tetra-sulfide on BXSB lupus-prone mice: a pilot study. Lupus. 2013;22(5): 469-476.

18. Ding WP, Zhang L, Kim SK, et al. Arsenic sulfide as a potential anti-cancer drug. Mol Med Rep. 2015;11(2):968-974.

19. Chen S, Fang Y, Ma L, Liu S, Li X. Realgar-induced apoptosis and differentiation in all-trans retinoic acid (ATRA)-sensitive NB4 and ATRA-resistant MR2 cells. Int J Oncol. 2012;40(4):1089-1096.

20. Yin $\mathrm{T}, \mathrm{Wu} \mathrm{YL}$, Sun HP, et al. Combined effects of $\mathrm{As}_{4} \mathrm{~S}_{4}$ and imatinib on chronic myeloid leukemia cells and BCR-ABL oncoprotein. Blood. 2004;104(13):4219-4225.

21. Wang H, Liu S, Lu X, Zhao X, Chen S, Li X. Gene expression profile changes in NB4 cells induced by realgar. Chin Med J (Engl). 2003;116(7):1074-1077.

22. Vogelstein B, Lane D, Levine AJ. Surfing the p53 network. Nature. 2000;408(6810):307-310.

23. Marchenko ND, Zaika A, Moll UM. Death signal-induced localization of p53 protein to mitochondria. A potential role in apoptotic signaling. J Biol Chem. 2000;275(21):16202-16212.

24. Ryan KM, Phillips AC, Vousden KH. Regulation and function of the p53 tumor suppressor protein. Curr Opin Cell Biol. 2001;13(3): 332-337.

25. Miyake H, Hara I, Hara S, Arakawa S, Kamidono S. Synergistic chemosensitization and inhibition of tumor growth and metastasis by adenovirus-mediated P53 gene transfer in human bladder cancer model. Urology. 2000;56(2):332-336.

26. Camp ER, Wang C, Little EC, et al. Transferrin receptor targeting nanomedicine delivering wild-type p53 gene sensitizes pancreatic cancer to gemcitabine therapy. Cancer Gene Ther. 2013;20(4): 222-228.

27. Zhao S, Zhang J, Zhang X, Dong X, Sun X. Arsenic trioxide induces different gene expression profiles of genes related to growth and apoptosis in glioma cells dependent on the p53 status. Mol Biol Rep. 2008;35(3):421-429.

28. Zhao S, Tsuchida T, Kawakami K, Shi C, Kawamoto K. Effect of $\mathrm{As}_{2} \mathrm{O}_{3}$ on cell cycle progression and cyclins D1 and B1 expression in two glioblastoma cell lines differing in p53 status. Int J Oncol. 2002; 21(1):49-55.

29. Jiang XH, Wong BC, Yuen ST, et al. Arsenic trioxide induces apoptosis in human gastric cancer cells through up-regulation of $\mathrm{p} 53$ and activation of caspase-3. Int J Cancer. 2001;91(2):173-179.

30. Chen SY, Zheng LZ, Liu JW, Li JY, Chen Q. Anticancer effects of realgar on MKN45 cells. Presented at: The 9th International Gastric Cancer Congress (9IGCC); April 20-23, 2011; Seoul. Abstract FP19-9.

31. Zhu GH, Wong BC, Ching CK, Lai KC, Lam SK. Differential apoptosis by indomethacin in gastric epithelial cells through the constitutive expression of wild-type p53 and/or up-regulation of c-myc. Biochem Pharmacol. 1999;58(1):193-200. 
32. Zhang YF, Zhang BC, Zhang AR, et al. Co-transduction of ribosomal protein L23 enhances the therapeutic efficacy of adenoviral-mediated p53 gene transfer in human gastric cancer. Oncol Rep. 2013;30(4): 1989-1995.

33. Li Y, Qu X, Qu J, et al. Arsenic trioxide induces apoptosis and G2/M phase arrest by inducing $\mathrm{Cbl}$ to inhibit PI3K/Akt signaling and thereby regulate p53 activation. Cancer Lett. 2009;284(2):208-215.

34. Tian Y, Liu Y, He P, et al. Arsenic sulfide promotes apoptosis in retinoid acid resistant human acute promyelocytic leukemic NB4-R1 cells through downregulation of SET protein. PLoS One. 2014;9(1):e83184.

35. Qi J, He P, Chen W, Wang H, Wang X, Zhang M. Comparative proteome study of apoptosis induced by $\mathrm{As}_{4} \mathrm{~S}_{4}$ in retinoid acid resistant human acute promyelocytic leukemia NB4-R1 cells. Leuk Res. 2010;34(11):1506-1516.

36. Miyashita T, Reed JC. Tumor suppressor p53 is a direct transcriptional activator of the human bax gene. Cell. 1995;80(2):293-299.

37. Oda E, Ohki R, Murasawa H, et al. Noxa, a BH3-only member of the Bcl-2 family and candidate mediator of p53-induced apoptosis. Science. 2000;288(5468):1053-1058.
38. Shen Y, Shenk T. Relief of p53-mediated transcriptional repression by the adenovirus E1B 19-kDa protein or the cellular Bcl-2 protein. Proc Natl Acad Sci U S A. 1994;91(19):8940-8944.

39. Hoffman WH, Biade S, Zilfou JT, Chen J, Murphy M. Transcriptional repression of the anti-apoptotic survivin gene by wild type p53. J Biol Chem. 2002;277(5):3247-3257.

40. Guo XG, Chen J, Zhang J. As $\mathrm{S}_{4}$ inducing apoptosis of gastric cancer cells SGC7901. Journal of Modern Oncology. 2013:21(11):2409-2412.

41. Muller PA, Vousden KH. p53 mutations in cancer. Nat Cell Biol. 2013;15(1):2-8.

42. Freed-Pastor WA, Prives C. Mutant p53: one name, many proteins. Genes Dev. 2012;26(12):1268-1286.

43. Freedman DA, Wu L, Levine AJ. Functions of the MDM2 oncoprotein. Cell Mol Life Sci. 1999;55(1):96-107.

\section{Publish your work in this journal}

Drug Design, Development and Therapy is an international, peerreviewed open-access journal that spans the spectrum of drug design and development through to clinical applications. Clinical outcomes, patient safety, and programs for the development and effective, safe, and sustained use of medicines are a feature of the journal, which has also been accepted for indexing on PubMed Central. The manuscript management system is completely online and includes a very quick and fair peer-review system, which is all easy to use. Visit http://www.dovepress.com/testimonials.php to read real quotes from published authors.

Submit your manuscript here: http://www.dovepress.com/drug-design-development-and-therapy-journal 